\title{
HISTORIA IMIGRACJI CHIŃCZYKÓW DO STANÓW ZJEDNOCZONYCH - DRUGA FALA
}

Niniejszy artykuł jest kontynuacją wątku podjętego w poprzednim zeszycie „Gdańskich Studiów Azji Wschodniej”, w którym w skrócie przedstawiłam całą historię imigracji Chińczyków do Stanów Zjednoczonych, natomiast szczegółowo opisałam jej pierwszą falę, przypadająca na lata 1848-1882¹. W tej części omówię trwająca ponad 60 lat druga falę imigracji, która rozpoczęła się w 1882 r. Ze względu na ograniczoną objętość artykułu ostatni fragment poświęcony trzeciej fali imigracji oraz zagadnieniom związanym ze współczesną polityką migracyjną zostanie opublikowany w następnym numerze.

Dwa lata po podpisaniu w Pekinie traktatu Angell między Stanami Zjednoczonymi a Chinami w dniu 7 listopada 1880 r., dzięki możliwościom, jakie wraz z jego wejściem w życie zyskały amerykańskie władze, pojawił się pomysł czasowego zawieszenia chińskiej imigracji do Stanów Zjednoczonych. Republikański senator John F. Miller, reprezentujący Kalifornię, zasugerował wprowadzenie ustawy, która zatrzymałaby proces imigracji Chińczyków na 20 lat. Wśród nowych przepisów był pomysł ustanowienia systemu certyfikacji i rejestracji przybyszów (prototyp paszportów i zielonych kart), kar za brak posiadania dokumentów imigracyjnych oraz zakaz naturalizacji Chińczyków nałożony na sądy stanowe i federalne. Mimo że projekt ustawy został ochoczo przyjęty zarówno w Senacie, jak i w Izbie Reprezentantów, ówczesny prezydent USA Chester A. Arthur skorzystał z prawa weta. Jego zdaniem okres 20 lat wykluczenia był zbyt długi. Kongres bardzo szybko wprowadził poprawki i zdecydował się na dziesięcioletnie wstrzymanie emigracji z Chin. Ustawa przeszła ponownie przez obie izby i 6 maja 1882 r. prezydent podpisał Chinese Exclusion Act. Prawo to zabraniało imigracji chińskich robotników, zarówno wykwalifikowanych, jak i niewykwalifikowanych, oraz określało grupy społeczne, którym można było odmówić wjazdu na teren Stanów Zjednoczonych. Ci, którzy chcieli po raz pierwszy przekroczyć granicę Ameryki, musieli posiadać pełną dokumentację wydaną przez chińskie placówki rządowe, potwierdzająca ich zawód oraz status uprawniający do imigracji ${ }^{2}$.

\footnotetext{
1 Zob. M. Paliszewska-Mojsiuk, Historia imigracii Chincsylkón do Stanów Zjednoczonych - pierwsza fala, „Gdańskie Studia Azji Wschodniej” 2018, z. 13, s. 51-62.

2 Jielin Dong, The Rocky Road to Liberty: A Documented History of Chinese Immigration and Exclusion, Saratoga 2010, s. 153-154.
} 
Na wprowadzenie Chinese Exclusion Act złożyły się trzy czynniki. Po pierwsze, imigranci z Chin byli uznawani za obcych. Ich wygląd zewnętrzny od razu zdradzał azjatyckie pochodzenie, co więcej, niezrozumiałe dla Amerykanów: chiński język, tradycje i obrządki tym bardziej zniechęcały do nich społeczeństwo. Po drugie, wszystkie decyzje usprawiedliwiano dobrem obywateli Stanów Zjednoczonych. Stosowane wobec Chińczyków ograniczenia i przepisy miały na celu zatrzymać napływ nowych imigrantów oraz wymusić deportację tych, którzy już przebywali na amerykańskiej ziemi. Po trzecie, potrzebowano narzędzia, które umożliwiłoby sprawowanie kontroli nad kolejnymi imigrantami poprzez nałożenie na nich prawnych ograniczeń oraz zakazu naturalizacji. Jednak wprowadzenie Chinese Exclusion Act było dopiero pierwszym etapem całkowitego powstrzymania migracji z Państwa Środka. Mieszkańcy Kalifornii podkreślali, że napływ Chińczyków tak naprawdę nie został zawieszony, a na dodatek pracodawcy oraz sądy federalne wykorzystywali luki prawne w przepisach i nadal zezwalali na migrację $e^{3}$.

W grudniu 1884 r. w San Francisco została podjęta uchwała, która wezwała rzadzących Kalifornią do wydania nowych przepisów dotyczących rejestracji oraz systemu deportacji imigrantów z Chin. Wszystko po to, aby zadbać o bezpieczeństwo obywateli Ameryki. Presja społeczna była tak wielka, że Kongres Stanów Zjednoczonych w tym samym roku wprowadził poprawkę do Chinese Exclusion Act, tym samym zaostrzając prawo. Obowiązywało ono już nie tylko nowych przybyszy z Chin, ale wszystkich robotników pochodzenia chińskiego, nakładało również szczegółowy proces identyfikacji osób należących do grup wykluczonych. Dyplomaci reprezentujący Stany Zjednoczone musieli sankcjonować certyfikaty wydawane przez administrację chińską. Byli oni również zobowiązani do sprawdzania autentyczności danych zawartych w dokumentach, a gdyby pojawiły się jakiekolwiek nieścisłości, urzędnicy dyplomatyczni mieli prawo unieważnić wszystkie dokumenty danej osoby dotyczace imigracji do Ameryki.

Co więcej, kupcy chcacy ubiegać się o certyfikat zezwalający na imigrację byli zobowiązani do przedstawienia informacji dotyczących natury i charakteru ich działalności oraz oszacowania jej wartości. Ustawa ograniczała również definicję zawodu kupca. Handlarze, domokrążcy oraz osoby zajmujące się przetwórstwem rybnym zostały wyłączone z definicji chińskiego kupca, a więc nie mogły ubiegać się o pozwolenie na migrację do USA. Chińczycy mogli podróżować do Ameryki „z ciekawości”, jednak ich certyfikat musiał określać, czy wnioskodawca planuje trasę wewnątrz Stanów Zjednoczonych, czy jedynie przejazd przez nie. Poza tym musiał również zawierać informację o sytuacji finansowej osoby ubiegającej się o wjazd do USA. Certyfikaty były głównymi dokumentami umożliwiającymi Chińczykom udział w procesie migracji, nie gwarantowały jednak, że zostaną oni przepuszczeni przez amerykańską granicę ${ }^{4}$.

3 E. Lee, At America's Gate: Chinese Immigration During the Exclusion Era, 1882-1943, Chapel Hill 2003, s. 20, 44.

4 Ibidem, s. 44-45. 
Opozycja uważała, że działania blokujące chińską imigrację stały się przyzwoleniem na rosnące w siłę ruchy antychińskie. Przemoc, zamieszki, ataki i masowe wydalenia rozprzestrzeniły się po Chinatown wielu miast. Apogeum niechęci wobec Chińczyków przypadło na rok 1885, kiedy to 28 września w Seattle na antychińskim wiecu wydano manifest, w którym zażądano wydalenia wszystkich Chińczyków ze stanu Waszyngton do 1 listopada 1885 r. W przeciwnym razie mieli zostać usunięci siła. Wiele osób pochodzenia chińskiego postanowiło opuścić stan przed datą zawartą w manifeście, bojąc się o swoje zdrowie i życie. Jednak nie wszyscy chcieli się zgodzić na porzucenie swojego miejsca zamieszkania. Pozostali na miejscu musieli stawić czoła wściekłemu tłumowi, który postanowił sam zmusić ich do ucieczki. Podobne nastroje były zauważalne również w innych stanach. Najgorsze zamieszki antychińskie wybuchły w Rock Springs, w stanie Wyoming, kiedy robotnicy chińskiego pochodzenia odmówili przyłączenia się do strajku u boku swoich białych współpracowników. Rozwścieczony tłum zaatakował grupę Chińczyków, w trakcie starcia 15 z nich zostało rannych, a 21 zabitych $^{5}$. W roku 1887 wskaźnik chińskiej migracji do Stanów Zjednoczonych osiąnną poziom zaledwie 10 osób ${ }^{6}$.

Kongres Stanów Zjednoczonych 13 września 1888 r. przyjął kolejną poprawkę do Chinese Exclusion Act, która wprowadziła jeszcze bardziej rygorystyczne warunki wykluczenia. Unieważniono prawo do powrotu do Ameryki chińskich robotników zamieszkujących już wcześniej w USA, a ich certyfikaty tożsamości zostały unieważnione. Jedynie mężczyźni mający w USA żonę z zalegalizowanego związku, dziecko lub rodzica, mienie o minimalnej wartości 1000 USD lub należne mu długi oczekujące spłaty, również w minimalnej wartości 1000 USD, mogli wrócić do Ameryki. Dodatkowo na mocy tej nowelizacji wszyscy Chińczycy, z wyjątkiem urzędników, nauczycieli, studentów, kupców oraz turystów, zostali pozbawieni prawa wjazdu do Stanów Zjednoczonych. W tym samym roku wprowadzono również Scott Act $^{7}$, który unieważniał certyfikaty ponad 20 tys. Chińczyków mieszkających w USA, a odwiedzających swoje rodziny w Chinach. Ponadto, sześciuset, którzy byli już w podróży do Ameryki, odmówiono prawa wjazdu, mimo że posiadali wydane przez rząd dokumenty uprawniające ich do powrotu do USA. Jednak reprezentanci Kalifornii nadal byli niezadowoleniu i oczekiwali jeszcze surowszych przepisów, zabraniających wszystkim Chińczykom, z wyjątkiem dyplomatów, wjazdu do Stanów Zjednoczonych. Mimo że żaden z proponowanych projektów ustaw nie został uchwalony, odzwierciedlało to cele zwolenników wykluczenia obywateli $\mathrm{Chin}^{8}$.

Kiedy zbliżał się koniec ważności obowiązywania ustawy uchwalonej na 10 lat, Kongres pośpiesznie przyzjął kolejną poprawkę, Geary Act ${ }^{9}$. Nowelizacja odna-

5 Jielin Dong, The Rocky Road..., s. 154.

6 E. Lee, At America's Gate..., s. 44.

7 Federalny akt prawny podpisany 1 października 1888 r. przez prezydenta Grovera Clevelanda.

8 E. Lee, At America's Gate..., s. 45.

9 Federalny akt prawny podpisany 5 maja 1892 r. przez prezydenta Benjamina Harrisona. 
wiająca obowiązywanie praw zawartych w Chinese Exclusion Act została zaproponowana przez Thomasa Geary'ego, demokratycznego senatora reprezentującego Kalifornię $^{10}$. Wykluczyła ona migrację chińskich robotników na kolejną dekadę, aż do 1902 r. Ponadto wymagała od wszystkich Chińczyków, którzy mają prawo przebywać na terytorium Stanów, ubiegania się o świadectwo meldunkowe nie później niż w rok od momentu wejścia w życie ustawy. Co więcej, byli oni również zobowiązani do ciagłego noszenia tych dokumentów przy sobie ${ }^{11}$.

W odpowiedzi na te restrykcje 19 września 1892 r. Chinese Six Companies ${ }^{12}$ (chiń. buiguăn - 会馆), stowarzyszenie zrzeszające Chińczyków w Stanach Zjednoczonych, wynajęło najlepszych prawników, aby udowodnić niekonstytucyjność Geary Act. Wezwali wszystkich imigrantów chińskiego pochodzenia, łącznie około 110 tys. osób, do buntu przeciwko procesowi ich uprzedmiotowienia. Nawoływano do stawiania oporu przeciw obowiązkowi rejestracji certyfikatów oraz noszenia z sobą karty ze zdjęciem, potwierdzającej ich status jako legalnego imigranta. Mimo że za nieposłuszeństwo wobec Dog Tag Law (z ang. ustawa znakowania psów), jak Geary Act było nazywane przez Chińczyków, groziła deportacja, tysiące osób dołączyły do prawdopodobnie największego aktu obywatelskiego nieposłuszeństwa. Pomysł obowiązku noszenia przy sobie pozwolenia na pobyt w USA wywodził się z czasów niewolnictwa. Przed wojną secesyjną niewolnicy opuszczający plantację, na której służyli, musieli mieć przy sobie dokumenty określające warunki przebywania poza nią.

Oczekując na decyzję sądu, tylko 3169 Chińczyków zarejestrowało się po odbiór certyfikatu. W 1893 r. Chińczycy przegrali w Sądzie Najwyższym i około 80\% chińskiej populacji USA powinno było zostać deportowane. Jednakże Kongres Stanów Zjednoczonych zdecydował się na kompromis i w tym samym roku wprowadził McCreary Amendment (poprawka McCreary’ego), która dawała dodatkowe 6 miesięcy na ubieganie się o certyfikaty, nie było to jednak podyktowane troską o Chińczyków. Sąd federalny Kalifornii wydał nakaz deportacji wszystkich niezarejestrowanych osób, jednak Kongres nie desygnował funduszy, aby wyegzekwować ten wyrok. $\mathrm{Na}$ dodatek rząd chiński poinformował Departament Stanu Stanów Zjednoczonych, że jeżeli Amerykanie podejmą jakiekolwiek kroki w celu deportacji Chińczyków, to Chiny zerwa wszelkie relacje z USA, a wszyscy obywatele Ameryki przebywający na terenie Chin będą musieli wrócić do swojej ojczyzny. Bez funduszy i poparcia Kongresu nie było możliwości zmusić Chińczyków do wyjazdu z USA. Wydłużenie okresu rejestracji było jedynym wyjściem, które pozwalało Stanom Zjednoczonym „zachować twarz”. Jednak poprawka McCreary’ego, oprócz ustalenia kwestii rejestracji, przypisywała kolejne zawody do definicji robotnika. W związku z tym rybacy,

10 E. Lee, At America's Gate..., s. 45.

11 Jielin Dong, The Rocky Road..., s. 155.

12 Zob. M. Paliszewska-Mojsiuk, Historia imigracji Chińczylków..., s. 56. 
górnicy, handlarze i właściciele pralni również zostali uznani za osoby, które nie mogły ubiegać się o prawo do imigracji1 $1^{13}$.

Stosunki dyplomatyczne i handlowe między Stanami Zjednoczonymi a Chinami maja podobnie długą historię jak migracja Chińczyków do USA. Pierwszy statek handlowy z Ameryki do Państwa Środka przepłynął Atlantyk w 1784 r., wioząc na pokładzie artykuły, które miały zainteresować Chińczyków: futra, bawełnę i ołów. Po sukcesie pierwszej wyprawy kolejne amerykańskie statki przypływały w celach handlowych do Chin. Największą przeszkodą w nawiązaniu stosunków z Państwem Środka było nieuznawanie innych krajów przez cesarza. Dla Chińczyków Chiny były całym światem, „wszystkim pod niebem” (z chiń. 天下 - tiānxiä), a władca był Synem Niebios. Rządzący innych państw nie mogli więc równać się z cesarzem, a amerykański konsul miał olbrzymie trudności, aby dotrzeć przed jego oblicze.

Podczas pierwszej wojny opiumowej (1838-1842) między Anglią a Chinami Stany Zjednoczone postanowiły pozostać neutralne. Wynikało to po części z antybrytyjskich nastrojów nadal utrzymujących się od czasu wojny o niepodległość USA. Pierwszy układ między Chinami a Stanami Zjednoczonymi podpisano 3 lipca 1844 r. Na jego mocy Amerykanie otrzymali prawie takie same przywileje jak Brytyjczycy w układzie z Nankinu, w tym dostęp do nowo otwartych portów (Kanton, Xiamen, Fuzhou, Ningbo oraz Szanghaj). Stany Zjednoczone uzyskały przywilej, którego nie udało się otrzymać Anglikom - obywatele amerykańscy popełniający przestępstwa na terenie Chin podlegali jurysdykcji amerykańskiej. Nie dotyczyło to wykroczeń naruszających ustalenia układu, czyli handlu zakazanymi towarami lub poza wyznaczonymi obszarami.

Wraz z rozwojem wymiany handlowej w amerykańskim rządzie rosła chęć rozwoju również stosunków dyplomatycznych. Mimo że układ z 1844 r. zapewniał przyjmowanie amerykańskich poselstw, cesarz nadal odmawiał spotkania z dyplomatami z USA. Podczas powstania tajpingów Stany Zjednoczone poparly rządy cesarskie, obawiając się, że po dojściu do władzy tajpingów w Chinach zapanuje chaos. Amerykanie nie włączali się w żadne działania zbrojne w Państwie Środka, jednak wykorzystywały osłabienie rządu chińskiego i korzystały z tych samych przywilejów co Anglicy czy Francuzi.

W 1861 r. do Chin przybył pierwszy amerykański poseł, który został bezpośrednio akredytowany przy cesarskim dworze, Anson Burlingame. Burlingame zaproponował, aby Stany Zjednoczone zastosowały odmienną politykę niż kraje europejskie, radził, aby nie angażować się w sprawy wewnętrzne Chin oraz nie wysuwać żadnych roszczeń terytorialnych czy handlowych. Po 6 latach służby dwór chiński zaproponował Burlingame’owi pozycję ambasadora Chin wśród państw nieazjatyckich, którą przyjął, a jego pierwsza podróżą w tej roli była delegacja do Ameryki. Wtedy

13 Jielin Dong, The Rocky Road..., s. 155; J. Pfaelzer, Driven Out: The Forgotten War against Chinese Americans, New York 2008, s. 291-299. 
to, w 1868 r. podpisano traktat Burlingame-Seward, który zapewniał obywatelom obu państw możliwość migracji. Był to ostatni traktat między Stanami Zjednoczonymi a Chinami, który został zawarty we względnej przyjaźni międzypaństwowej. Kolejne wydarzenia związane z wykluczaniem Chińczyków z terytorium Ameryki nie wpływały pozytywnie na wzajemne relacje $\mathrm{e}^{14}$.

W 1898 r. rozszerzono obszar obowiązywania Chinese Exclusion Act. Po tym jak prezydent William McKinley podpisał uchwałę, która przyłączała Republikę Hawajów jako terytorium zależne Stanów Zjednoczonych, akty federalne Ameryki zaczęły obowiązywać również w obrębie wysp Hawajów. Dalsza ekspansja uchwały nastapiła w 1902 r., kiedy Kongres Stanów Zjednoczonych podpisał kolejne przedłużenie Chinese Exlusion Act oraz rozszerzył terytorium mocy swoich praw na wszystkie wyspy w posiadaniu Ameryki, łącznie z Filipinami ${ }^{15}$. W 1904 r. ponownie wydłużono czas obowiązywania tego prawa, tym razem bezterminowo. Chińczycy, czując się poniżeni, w 1905 r. rozpoczęli bojkot amerykańskich towarów i biznesów, które bardzo dobrze prosperowały w największych miastach Chin. Chińscy pracownicy amerykańskich firm w Państwie Środka zaprzestali pracy, unieważniali kontrakty lub opuszczali budynki należące do Amerykanów. Mimo że protest ten nie przyniósł większych rezultatów, pozbawił amerykański budżet około 30-40 mln USD i pokazał solidarność obywateli Chin z ich rodakami w USA ${ }^{16}$.

Chińscy mężczyźni mieszkający w Stanach Zjednoczonych pragnęli sprowadzić tam swoje pozostawione w ojczyźnie rodziny. Niestety tylko kupcy mogli wyemigrować do Ameryki wraz z najbliższymi. Reprezentantom pozostałych zawodów praczom, rybakom czy robotnikom, którzy mieszkali w USA, pozostało poszukiwanie luk w prawie imigracyjnym. W ten sposób powstała idea paper merchants (z ang. papierowi kupcy). Chińczycy o gorszym statusie przekupywali kupców lub kupowali udziały w ich biznesach, aby znaleźć się na liście współwłaścicieli. Otwierano również wiele fałszywych sklepów tylko po to, aby zapewnić fikcyjne miejsca pracy. Jednak mimo prób obejścia legislacji większość chińskich robotników nie żywiła nadziei na zamieszkanie z rodziną na amerykańskiej ziemi.

Wszystko miało się zmienić 18 kwietnia 1906 r. Tego dnia San Francisco zostało zdewastowane podczas trzęsienia ziemi, po którym w całym mieście rozgorzały pożary, niszcząc wszelką dokumentację dotyczącą mieszkańców. Ta katastrofa naturalna zmieniła bieg historii dla chińskich imigrantów. Pozwoliła Chińczykom twierdzić, że ich miejscem urodzenia było San Francisco. Bez ksiąg ludności urzędnicy nie mieli możliwości sprawdzenia autentyczności tych danych i musieli wierzyć na słowo osobom ubiegającym się o nowe dokumenty. Dzięki temu wielu Chińczyków, którzy nie mogli liczyć na naturalizację, stało się obywatelami USA. Amerykańskie

14 L. Pastusiak, Dyplomacja Stanów Zjednoczonych (XVIII-XIX w.), Toruń 1997, s. 457-468, 601-614.

15 E. Lee, At America's Gate..., s. 45-46.

${ }_{16}$ Jielin Dong, The Rocky Road..., s. 155. 
obywatelstwo dało robotnikom prawo do podróżowania między Stanami Zjednoczonymi a Chinami, co wcześniej było dla nich niedostępne na mocy Scott Act z 1888 r. Co więcej, będąc obywatelami USA, mogli legalnie sprowadzić swoje żony do Ameryki, a ich urodzone poza granicami kraju dzieci również były uprawnione do amerykańskiego obywatelstwa.

Prawo to spowodowało powstanie kolejnego procederu, który miał na celu oszukanie legislacji imigracyjnej. Ponieważ rejestry urodzeń z Chin były prawie niemożliwe do zdobycia przez urzędników imigracyjnych USA, stosunki między ojcami a synami były zwykle poświadczane na podstawie zeznań innych członków rodziny lub znajomych. Chińczycy, którzy chcieli wyemigrować do USA, odkupowali akty urodzenia od Amerykanów chińskiego pochodzenia i podawali się za ich synów, aby również uzyskać obywatelstwo. Osoby, które w ten sposób próbowały dostać się do Stanów Zjednoczonych, były nazywane paper sons (z ang. papierowi synowie), ponieważ ich pokrewieństwo $z$ domniemanymi ojcami istniało jedynie na papierze. Jednak posiadanie aktu urodzenia nie zawsze oznaczało przyjęcie do USA, po dotarciu do wybrzeży Kalifornii musieli również potwierdzić swoją amerykańską tożsamość. Wraz z dokumentami papierowi synowie otrzymywali książeczki z opisem całej rodziny swojego fikcyjnego ojca. Podczas podróży do Ameryki uczyli się na pamięć imion członków „papierowej rodziny”, ważnych dat oraz wszystkich szczegółów dotyczących m.in. ich miejsca zamieszkania. Przed dotarciem do portu niszczyli książeczki i wrzucali je do wody, aby pozbyć się jakichkolwiek dowodów oszustwa, gdyż w przypadku jego wykrycia zarówno oni, jak i cała „papierowa rodzina" ponieśliby konsekwencje prawne. Nie istnieją rejestry, które określałyby, ilu Chińczyków nadużyło sytuacji po trzęsieniu ziemi. Jednak w przybliżeniu obliczono, że gdyby wszystkie roszczenia dotyczące naturalnego pochodzenia obywatelskiego były zasadne, to każda Chinka w San Francisco musiałaby urodzić po około osiemset dzieci ${ }^{17}$.

American Bureau of Immigration (Amerykański Urząd Imigracyjny) potrzebował miejsca na właściwe zbadanie osób przybyłych z Chin. Na początku XX wieku urzędnicy imigracyjni wsiadali na statki przypływające do wybrzeża Ameryki i bezpośrednio na nich dokonywali czynności przepytywania i badania imigrantów. Od 1903 r. amerykański rząd rozważał budowę specjalnej stacji imigracyjnej na wyspie Angel, położonej w zatoce San Francisco. Propozycja budowy na wyspie była doskonałym argumentem - w ten sposób skutecznie można było oddzielić przybyszy zarówno od ich rodzin, które mogłyby próbować ich przygotować na przesłuchania, jak i od Amerykanów, dla których nieprzebadani imigranci „mogli stanowić zagrożenie". Co więcej, z wyspy nikt nie mógł uciec ze względu na odległość od stałego lądu. Podobna stacja działała od 1892 r. na wschodnim wybrzeżu, na wyspie Ellis, dla imigrantów przybywających z Europy. W 1905 r. Kongres zatwierdził po-

17 R. Takaki, Strangers from a Different Shore: A History of Asian Americans, Boston 1989, s. 234-236. 
mysł wzniesienia stacji imigracyjnej na wyspie Angel, a budowę zakończono 3 lata później. Pomimo protestów chińskich organizacji 21 stycznia 1910 r. stacja została otwarta i już następnego dnia przybyli do niej pierwsi imigranci.

Po otwarciu stacji wskaźnik odrzuceń w porównaniu z latami poprzednimi był o około 90\% wyższy. Chińczycy obwiniali instytucjonalizację imigracji za wzrost liczby odrzuconych; protestowali również przeciwko nieodpowiedniemu traktowaniu przez urzędników oraz złym warunkom socjalnym w kwaterach, w których mieszkali ${ }^{18}$. Po dotarciu do wyspy imigranci byli prowadzeni do baraków sypialnych. Obywatele różnych nacji żyli oddzielnie, rozdzielano również rodziny. Żony i mężowie nie mogli się spotykać przez cały okres procesu imigracyjnego, jedynie dzieci w wieku do 12 lat mogły pozostać przy swoich matkach ${ }^{19}$. Na terenie stacji imigranci byli wielokrotnie przesłuchiwani oraz poddawani wielu badaniom lekarskim, co sugerowało, że przybysze z Azji stanowią większe zagrożenie dla Ameryki niż osoby z innych części świata. Dodatkowo przedstawiciele służby zdrowia pracujący na wyspie Angel mieli osobne zalecenia, do których mieli się stosować przy badaniu osób pochodzących z Chin. Poszukiwali pospolitych orientalnych chorób i pasożytów, które nie stanowiły zagrożenia dla ludności amerykańskiej, jednak były wystarczającym pretekstem do zatrzymania osoby na wyspie lub wydania zakazu wjazdu do USA. Warunki socjalne na stacji również były przyczyną złego stanu zdrowia imigrantów. Przeludnione sale sypialne, złe warunki sanitarne łazienek czy zezwolenie na opuszczenie kwater tylko dwa razy w tygodniu i to tylko na pół godziny zwiększały ryzyko choroby ${ }^{20}$. Badania medyczne i przesłuchania były tak szczegółowe i intensywne, że przybysze musieli spędzić na wyspie co najmniej tydzień, a niektórzy nawet wiele miesięcy, dopóki ich stan zdrowia się nie poprawił lub nie przekonali władz imigracyjnych, że ich dokumenty są ważne ${ }^{21}$. Wszystkie procedury przeprowadzane w stacji wykazywały nieufność, jaką amerykański rząd odczuwał wobec Chińczyków ${ }^{22}$.

Przedstawiciele klas, które swobodnie mogły ubiegać się o przyjęcie na amerykańskiej ziemi, tj. kupcy, studenci i urzędnicy, nie byli automatycznie zwalniani z przesłuchań i badań. Urzędnicy imigracyjni utrzymywali, że większość Chińczyków przybywających do USA jako reprezentanci jednej z wyżej wymienionych grup to w rzeczywistości robotnicy „w przebraniu”. Każdy obywatel Chin przypływający do Ameryki był najpierw oceniany przez pryzmat bycia Chińczykiem, a dopiero potem pod katem swojego statusu. $\mathrm{Na}$ wypadek gdyby wszystkie poprzednie regulacje ograniczające napływ Chińczyków do Stanów Zjednoczonych nie były wystarczające, pomimo wcześniejszego veta prezydenta Woodrowa Wilsona w 1916 r.,

18 E. Lee, At America's Gate..., s. 126-128.

19 Ibidem, s. 81; R. Takaki, Strangers from a Different Shore..., s. 237.

20 E. Lee, At America's Gate..., s. 81-83, 127-128.

21 R. Takaki, Strangers from a Different Shore..., s. 238.

22 E. Lee, At America's Gate..., s. 85. 
uchwalono Immigration Act of $1917^{23}$. Na mocy tej ustawy imigracyjnej obywatele krajów azjatyckich (z wyjątkiem Japonii i Filipin) oraz Bliskiego Wschodu zostali pozbawieni prawa do migracji na teren Stanów Zjednoczonych. Jedynie urzędnicy, kupcy, nauczyciele i podróżnicy mogli liczyć na zgodę na wjazd do USA. Nałożono również obowiązkową opłatę w wysokości 8 USD $^{24}$, którą musiała wnieść każda osoba powyżej 16 roku życia ubiegająca się o przyjęcie na amerykańskiej ziemi. Aby pozbyć się osób niepożądanych, tj. m.in. alkoholików, kryminalistów, analfabetów, żebraków, prostytutek, poligamistów czy osób umysłowo chorych ${ }^{25}$, Immigration Act of 1917 wprowadzał obowiązkowy test umiejętności czytania. Wszystkie osoby w wieku powyżej 16 lat, fizycznie zdolne do czytania i mówienia musiały przejść test, który polegał na przeczytaniu tekstu składającego się z 30-40 słów w rodzimym języku imigranta, mógł to być również wybrany przez niego dialekt. Obowiazek przejścia sprawdzianu umiejętności czytania dotyczył nie tylko mieszkańców Azji, ale również Europejczyków. Była to pierwsza ustawa, która miała na celu ograniczenie, a nie tylko prawną regulację migracji z Europy ${ }^{26}$.

W 1922 r. wprowadzono Cable Act ${ }^{27}$, pozbawiający amerykańskiego obywatelstwa te kobiety, które zawarły związek małżeński z cudzoziemcem niemającym prawa do ubiegania się o naturalizację, a więc dotyczyło to tylko Azjatów. Akt ten bardzo mocno uderzał w Amerykanki pochodzenia azjatyckiego, które często wiazały się z obywatelami swoich rodzimych krajów. Wraz z utratą obywatelstwa pozbawiane były również praw obywatelskich ${ }^{28}$.

Emergency Quota Act ${ }^{29}$ podpisany w 1921 r. był pierwszym dokumentem, który ustanawiał etniczny system kwotowy dotyczący imigracji do Stanów Zjednoczonych. Wraz z wprowadzeniem limitów migracyjnych powstał National Origins Formula - używany w latach 1921-1965 system polegający na wyliczaniu kwot migrantów na podstawie proporcji amerykańskiej ludności. Jego celem było zmniejszenie napływu niewyszkolonych robotników oraz utrzymanie etnicznej równowagi w USA. Emergency Quota Act ograniczał liczbę osób, które mogły ubiegać się o przyjęcie w Stanach Zjednoczonych do 3\% populacji danej narodowości w USA zgodnie z danymi ze spisu ludności z 1910 r. Ustawa ta promowała migrację obywateli z krajów Europy Północnej, których było znacznie więcej w Stanach Zjednoczonych

${ }^{23}$ Federalny akt prawny ustanowiony przez Kongres 5 lutego 1917 r. po wecie prezydenta Woodrowa Wilsona.

24 Równowartość 170 USD w 2018 r., na podstawie: https://www.dollartimes.com/inflation/ inflation.php?amount=8\&year=1917 (dostęp: 29.10.2018).

25 Immigration Act of 1917, http://library.uwb.edu/Static/USimmigration/39\%20stat $\% 20$ 874.pdf (dostęp: 29.10.2018).

26 J. Powell, Encyclopedia of North American Immigration, New York 2005, s. 137.

${ }^{27}$ Federalny akt prawny podpisany 22 września 1922 r. przez prezydenta Warrena G. Hardinga.

28 E. Lee, At America's Gate..., s. 39, 87.

29 Federalny akt prawny podpisany 19 maja 1921 r. przez prezydenta Warrena G. Hardinga. 
w 1910 r., w odróżnieniu od obywateli uboższych krajów Europy Wschodniej. Nie ustanawiała ona jednak żadnych limitów dla migrujących z Ameryki Łacińskiej ani nie wpływała na liczbę obywateli krajów Azji i Bliskiego Wschodu, gdyż ci na mocy Immigration Act of 1917 nadal byli pozbawieni możliwości migracji do USA. Mimo że liczba przyjmowanych rocznie imigrantów spadła, to amerykański rząd nie był w pełni zadowolony ze skuteczności tej ustawy. W 1924 r. podpisano Immigration Act of $1924^{30}$, który zmniejszał limity do $2 \%$ populacji danej narodowości zamieszkującej w Stanach Zjednoczonych zgodnie z danymi spisu ludności z 1890 r., lecz nie mniej niż sto osób danej nacji. Nie dość, że limit procentowy został obniżony, to również populacja imigrantów w 1890 r. była niższa niż w 1910 r., który był punktem odniesienia w poprzedniej ustawie. Nadal nie wpływała ona jednak ani na migrację z Ameryki Łacińskiej, ani na tę z krajów azjatyckich, ponieważ wciąż obowiązywał Immigration Act of $1917^{31}$.

Sytuacja chińskich imigrantów miała się niebawem zmienić. W 1943 r. prezydent Franklin D. Roosevelt podpisał Magnusson Bill ${ }^{32}$, ustawę, która uchylała wszystkie poprzednie prawa limitujące napływ Chińczyków do Stanów Zjednoczonych. Prezydent podkreślił, jak ważne jest to wydarzenie, biorąc pod uwage sytuację wojenną ${ }^{33}$. Jednak był to tylko symboliczny gest przyjaźni między Ameryką a Chinami. Po wprowadzeniu Magnusson Bill Chińczyków zaczęły obowiązywać przepisy Immigration Act of 1924. Limit kwotowy, ustalony na podstawie populacji Chińczyków w USA w 1890 r., wynosił jedynie 105 osób rocznie, co nie pozwala na stwierdzenie, że Ameryka otworzyła się na migrantów z Chin. Był to jednak pierwszy krok ku znormalizowaniu imigracji z Państwa Środka. Ponadto Chińczycy nareszcie mogli być naturalizowani. Dopiero następne lata miały przynieść kolejne korzyści dla nich ${ }^{34}$.

Przez ponad 6 dekad obywatele Chin byli pozbawieni możliwości migracji do Stanów Zjednoczonych, a tym, którzy mieli więcej szczęścia i zamieszkiwali na amerykańskiej ziemi, odmawiano naturalizacji. Mimo to Chińczycy nie poddawali się. Byli zdeterminowani, aby żyć w USA, spędzali całe tygodnie w centrum imigracyjnym na wyspie Angel, przechodzili niezliczone przesłuchania i badania, a każda wątpliwość była wykorzystywana przeciwko nim. Wraz z podpisaniem Magnusson Bill zakończyła się druga fala emigracji Chińczyków do Stanów Zjednoczonych, a rozpoczął się okres usystematyzowanej, legalnej migracji.

\footnotetext{
30 Federalny akt prawny podpisany 24 maja 1924 r. przez prezydenta Calvina Coolidge'a.

31 E. Lee, At America's Gate..., s. 238, 245-246.

32 Federalny akt prawny podpisany 17 grudnia 1943 r. przez prezydenta Franklina D. Roosevelta.

33 https://www.presidency.ucsb.edu/documents/statement-signing-the-bill-repeal-the-chineseexclusion-laws (dostęp: 29.10.2018).

34 E. Lee, At America's Gate..., s. 245.
} 


\section{SUMMARY}

\section{THE SECOND WAVE OF CHINESE IMMIGRATION TO THE UNITED STATES OF AMERICA}

Chinese immigrants are the third-largest, foreign-born group in the United States. This article aims to investigate the second wave of Chinese immigration to the United States, which started in 1882 when the US Congress passed the Chinese Exclusion Act. Since the beginning of their immigration to the USA, the Chinese struggled with the reluctance of white American society and US officials toward them. America had many reservations against foreigners from China crossing their borders. Behind this ideology lay mainly a lack of knowledge about Chinese language, traditions and culture; moreover, the outer appearance of the Chinese made them easily recognizable, which led to prejudice. Chinese immigrants were perceived as sojourners not willing to settle in America permanently, which increased that aversion. For about 60 years - for that is how long the second wave lasted - the American government looked for any solution to keep the Chinese away from its borders, starting with the Chinese Exclusion Act, through its amendments broadening that legislation, up to when it built the immigration center on Angel Island, where the Chinese were interrogated and checked for bacteria and illnesses, and whether they were to be given the right to enter the country. The second wave ended in 1943 after president Franklin D. Roosevelt signed the Magnusson Bill which repealed the discriminatory laws against the Chinese. The migration policy imposed on the Chinese is believed to have been the only one in the US that prevented migration and naturalization on the basis of race. 